\title{
Perancangan Arsitektur Data Pada Fungsi Analisis Kondisi Umum Daerah Kabupaten Bintan Menggunakan Framework TOGAF ADM
}

\author{
Mochammad Rizki Romdoni ${ }^{1}$ \\ ${ }^{1}$ Teknik Informatika, Sekolah Tinggi Teknologi Indonesia Tanjungpinang \\ ${ }^{1}$ Jln. Pompa Air No. 28 Tanjungpinang Kepulauan Riau Indonesia \\ rizki@sttindonesia.ac.id ${ }^{1}$
}

\begin{abstract}
Intisari-Badan Perencanaan, Pembangunan, Penelitian, dan Pengembangan (BAPELITBANG) Kabupaten Bintan, salah satu dari tugasnya adalah mempersiapkan RPJMD (Rencana Pembangunan Jangka Menengah) yang dikenal sebagai RPJMD teknokratik. Saat mempersiapkan RPJMD dibutuhkan data dan informasi kondisi umum daerah, yang digunakan sebagai dasar untuk mengeksplorasi, memproyeksikan, memprediksi kondisi lima tahun ke depan. Ada beberapa tahapan sebelum melakukan proses analisis data dan analitik, salah satunya adalah data preprocessing. Salah satu kesulitan yang dihadapi oleh BAPELITBANG adalah tahapan data preprocessing, karena data tersebar di Organisasi Perangkat Daerah (OPD) dengan berbagai macam format. Solusi untuk menyelesaikan permasalahan ini dimulai dari merancang arsitektur data. Framework yang digunakan untuk merancang arsitektur adalah The Open Group Arcitecture Framework (TOGAF) Architecture Development Method (ADM) Fase C, yaitu Arsitektur Sistem Informasi. Hasil dari Perancangan adalah cetak biru (Blueprint) yang dapat digunakan sebagai panduan dalam mengimplementasikan dan sebagai basis ke tahapan selanjutnya, yaitu data cleansing, data filter / enrich, classification, data analytics, modelling prediction, data delivery, dan data visualization.
\end{abstract}

Kata kunci- Analisis Kondisi Umum Daerah, big data, data science, TOGAF Information System Architecture

\begin{abstract}
Badan Perencanaan, Pembangunan, Penelitian, dan Pengembangan (BAPELITBANG) Kabupaten Bintan, one of the tasks is to preparing RPJMD (medium-term development plan) called RPJMD teknokratik. When preparing RPJMD are needed data and information for analysis general condition of the regions which are used as a basis for exploring, projecting, predicting the condition of the coming five years. There are several steps before performing data analysis and data analytics process, one of which is data preprocessing. The main obstacle faced by BAPELITBANG is at the stage of data preprocessing, data collection spread in the Organisasi Perangkat Daerah (OPD) in various format. The solution to overcome these obstacles starts with designing a data architecture. The framework used in designing this data architecture is The Open Group Architecture Framework (TOGAF) Architecture Development Method (ADM) phase C, namely information system architecture. The design result is a blueprint that can be used as an implementation guide and as a basis for entering into the next stage, data cleansing, data filter/enrich, classification, data analytics, modeling prediction, data delivery, and visualization.
\end{abstract}

Keywords- Analisis Kondisi Umum Daerah, big data, data science, TOGAF Information System Architecture

\section{Pendahuluan}

Salah satu aktivitas dalam perencanaan pembangunan daerah berdasarkan [1] adalah melakukan analisis kondisi umum daerah yang mencakup kondisi geografis, demografi, potensi sumber daya, ekonomi dan keuangan; ditambah dengan indikator kinerja kunci penyelenggaraan pemerintahan daerah meliputi aspek kesejahteraan masyarakat, aspek pelayanan umum, dan aspek daya saing daerah.

Analisis kondisi umum daerah bertujuan untuk menghasilkan dan memutakhirkan gambaran umum kondisi daerah yang diperlukan untuk menunjang perencanaan pembangunan daerah dengan cara memprediksi kondisi dan perkembangan daerah melalui penggunaan formula/rumus perhitungan baku terhadap obyek tertentu; melihat tren (kecenderungan), atau menggunakan asumsi berdasarkan hasil pengamatan obyek tertentu.
Tantangan yang muncul dalam analisa kondisi umum daerah adalah ketersediaan (availability), keakuratan (accuracy), dan kelengkapan (completeness) data; yang saat ini kondisinya masih belum maksimal.

Langkah awal dalam menjawab tantangan tersebut adalah merancang sebuah Enterprise Architecture (EA) sebagai basis arsitektur dalam penyediaan data untuk analisa kondisi umum daerah dengan menggunakan teknologi big data dan data analytics.

Perancangan EA ini menggunakan framework TOGAF (The Open Group Architecture Framework). Penelitian sebelumnya mengenai perancangan EA pada fungsi perencanaan pembangunan daerah telah dilaksanakan pada BAPPEDA Kabupaten Bandung[2], yang menghasilkan roadmap pengembangan dan integrasi sistem informasi serta konfigurasi-konfigurasi yang berkaitan dengannya.

TOGAF mendefiniskan enterprise sebagai gabungan organisasi yang memiliki kesamaan tujuan. Contoh dari enterprise yaitu sebuah organisasi pemerintah, sebuah 
perusahaan, atau sebuah departemen dalam perusahaan [3]. Enterprise di dalam penelitian ini adalah Badan Perencanaan Pembangunan, Penelitian, dan Pengembangan (BAPELITBANG) Kabupaten Bintan yang memiliki tugas pokok[1] mengoordinasikan penyusunan, pengendalian, dan evaluasi pelaksanaan perencanaan pembangunan.

Gambar 1 adalah framework TOGAF ADM, yang terdiri dari sembilan fase mulai dari fase Preliminary sampai dengan architecture change management. Penelitian dibatasi pada fase C yaitu perancangan Information System Archictecture di tahap arsitektur data.

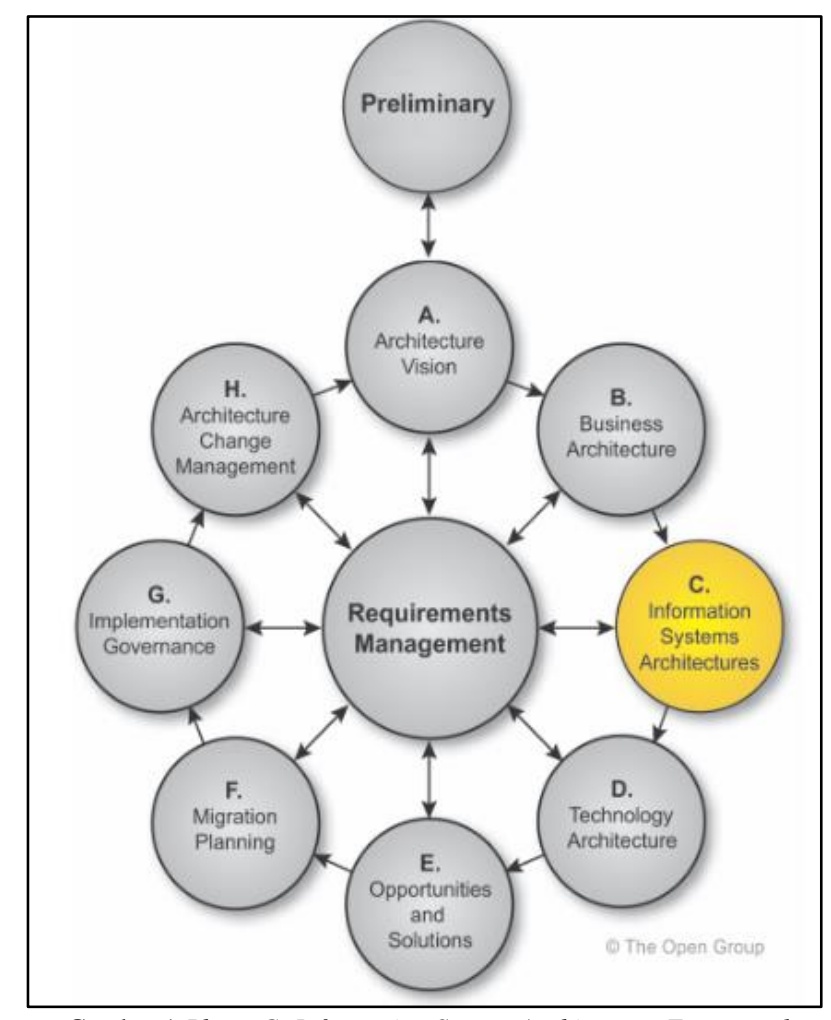

Gambar 1 Phase C: Information System Architecture Framework TOGAF ADM

Hasil dari penelitian ini adalah sebuah blueprint; dengan adanya blueprint ini memberikan sebuah gambaran tahapan atau komponen apa yang akan di implementasikan ke sebuah sebuah prototipe dalam rangka untuk menyediakan data atau informasi kondisi umum daerah.

\section{LANDASAN TEORI}

\section{A. Analisis Kondisi Umum Daerah}

Analisis kondisi umum daerah merupakan bagian sangat penting dalam RPJMD yang secara sistematika berada pada bab II dokumen RPJMD, yang dengannya tim penyusun RPJMD mendapatkan data dan informasi mengenai gambaran kondisi riil daerah sebagai dasar untuk menetapkan ukuran indikator sasaran atau program perencanaan selama periode lima tahun RPJMD.

Merujuk pada peraturan Menteri Dalam Negeri No. 86 Tahun 2017 [1] data yang harus disediakan harus dapat memenuhi proses analisa terhadap empat aspek yaitu :

\section{1) Aspek Geografi dan Demografi}

Analisis pada aspek geografi perlu dilakukan untuk memperoleh gambaran mengenai karakteristik lokasi dan wilayah, potensi pengembangan wilayah, dan kerentanan wilayah terhadap bencana; sedangkan aspek demografi menggambarkan kondisi penduduk secara keseluruhan atau kelompok dalam waktu tertentu.

\section{2) Aspek Kesejahteraan Masyarakat}

Aspek kesejahteraan masyakarat terdiri dari kesejahteraan ekonomi dan pemerataan ekonomi, kesejahteraan sosial, serta seni budaya dan olahraga. Untuk menganalisis, terlebih dahulu disusun tabel capaian indikator setiap variabel yang akan dianalisis menurut kecamatan. Indikator variabel yang dimaksud terdiri dari :

1. Fokus Kesejahteraan dan Pemerataan Ekonomi

2. Fokus Kesejahteraan Sosial

3. Fokus Seni Budaya dan Olahraga

3) Aspek Pelayanan Umum

Pelayanan publik atau umum merupakan segala bentuk jasa pelayanan, baik dalam bentuk barang publik maupun jasa public yang menjadi tanggungjawab Pemerintah Daerah. Untuk menganalisis terlebih dahulu disusun tabel capaian indikator setiap variabel yang akan dianalisis menurut kecamatan. Indikator variabel yang dimaksud terdiri :

1. Fokus Layanan Umum Urusan Pemerintah Wajib

2. Fokus Layanan Urusan Pemerintah Pilihan

4) Aspek Daya Saing Daerah

Aspek daya saing daerah terdiri dari kemampuan ekonomi daerah, fasilitas wilayah atau infrastruktur, iklim berinvestasi dan sumber daya manusia. Indikator variabel terdiri dari :

1. Fokus Kemampuan Ekonomi Daerah

2. Fokus Fasilitas Wilayah/Infrastruktur

3. Fokus Iklim Berinvestasi

4. Fokus Sumber Daya Manusia

Aspek dan fokus memiliki atribut data berupa kondisi atau indikator. Tabel 1 menunjukan contoh kecil atribut yang dibutuhkan. BAPELITBANG bisa menambahkan atribut data tersebut sesuai dengan kebutuhan perencanaan pembangunan daerah.

TABEL I

KEBUTUHAN DATA

\begin{tabular}{|c|c|c|}
\hline NO & ASPEK / FOKUS & ATRIBUT \\
\hline A & Aspek Geografi dan Demografi & \\
\hline \multirow[t]{2}{*}{ A. 1} & \multirow[t]{2}{*}{ Karakteristik lokasi dan wilayah } & $\begin{array}{l}\text { Luas dan batas wilayah } \\
\text { administrasi }\end{array}$ \\
\hline & & $\begin{array}{l}\text { Letak dan kondisi } \\
\text { geografis antara lain } \\
\text { terdiri dari : posisi } \\
\text { astronomis, posisi } \\
\text { geostrategik, topografi, } \\
\text { dan lain-lain }\end{array}$ \\
\hline
\end{tabular}




\begin{tabular}{|c|c|c|}
\hline & & $\begin{array}{l}\text { Potensi pengembangan } \\
\text { wilayah }\end{array}$ \\
\hline & & $\begin{array}{ll}\text { Wilayah } & \text { Rawan } \\
\text { Bencana } & \\
\end{array}$ \\
\hline \multirow[t]{5}{*}{ A. 2} & \multirow[t]{5}{*}{ Demografi } & $\begin{array}{lr}\text { jumlah dan } & \text { struktur } \\
\text { umur } & \text { penduduk } \\
\text { berdasarkan } & \text { jenis } \\
\text { kelamin } & \end{array}$ \\
\hline & & $\begin{array}{l}\text { laju pertumbuhan } \\
\text { penduduk; }\end{array}$ \\
\hline & & $\begin{array}{lr}\text { dinamika } & \text { penduduk } \\
\text { yang dipengaruhi oleh } \\
\text { kelahiran, kematian } \\
\text { dan } \\
\text { perpindahan } \\
\text { penduduk; }\end{array}$ \\
\hline & & $\begin{array}{l}\text { distribusi/persebaran } \\
\text { penduduk; }\end{array}$ \\
\hline & & $\begin{array}{lr}\text { komposisi } & \text { dan } \\
\text { populasi masyarakat } \\
\text { yang disusun secara } \\
\text { keseluruhan } \\
\text { atau kelompok tertentu } \\
\text { didasarkan rada } \\
\text { kriteria raperti } \\
\text { pendidikan, } \\
\text { kewarganegaraan, } \\
\text { agama, atau entitas } \\
\text { tertentu. }\end{array}$ \\
\hline B & Aspek Kesejahteraan Masyarakat & \\
\hline \multirow[t]{2}{*}{ B.1 } & \multirow[t]{2}{*}{$\begin{array}{l}\text { Fokus Kesejahteraan dan Pemerataan } \\
\text { Ekonomi }\end{array}$} & $\begin{array}{l}\text { Pertumbuhan PDRB } \\
\text { (Produk Domestik } \\
\text { Regional Bruto) }\end{array}$ \\
\hline & & Laju Inflasi \\
\hline \multirow[t]{2}{*}{ B.2 } & \multirow[t]{2}{*}{ Fokus Kesejahteraan Sosial } & Angka Melek Huruf \\
\hline & & Rata-rata lama sekolah \\
\hline \multirow[t]{4}{*}{ B.3 } & \multirow[t]{4}{*}{ Fokus Seni budaya dan Olahraga } & $\begin{array}{l}\text { Jumlah grup kesenian } \\
\text { per } 10.000 \text { penduduk }\end{array}$ \\
\hline & & $\begin{array}{ll}\text { Jumlah } & \text { gedung } \\
\text { kesenian per } & 10.000 \\
\text { penduduk. } & \\
\end{array}$ \\
\hline & & $\begin{array}{l}\text { Jumlah klub olahraga } \\
\text { per } 10.000 \text { penduduk }\end{array}$ \\
\hline & & $\begin{array}{l}\text { Jumlah klub olahraga } \\
\text { per } 10.000 \text { penduduk }\end{array}$ \\
\hline $\mathrm{C}$ & Aspek Pelayanan Umum & \\
\hline \multirow[t]{4}{*}{ C.1 } & \multirow[t]{3}{*}{$\begin{array}{llll}\text { Fokus Layanan Urusan Pemerintah } \\
\text { Wajib }\end{array}$} & $\begin{array}{l}\text { Angka } \\
\text { wajib }\end{array}$ \\
\hline & & $\begin{array}{ll}\text { Angka } & \text { Partisipasi } \\
\text { Sekolah } & \\
\end{array}$ \\
\hline & & $\begin{array}{l}\text { Rasio Ketersediaan } \\
\text { Sekolah per penduduk } \\
\text { usia sekolah }\end{array}$ \\
\hline & & Rasio Guru Murid \\
\hline \multirow[t]{3}{*}{ C.2 } & \multirow[t]{3}{*}{$\begin{array}{llll}\begin{array}{l}\text { Fokus Layanan } \\
\text { Pilihan }\end{array} & \text { Urusan Pemerintah } \\
& & \\
\end{array}$} & $\begin{array}{l}\text { Jumlah Investor skala } \\
\text { Nasional } \\
\text { (PMDN/PMA) }\end{array}$ \\
\hline & & $\begin{array}{l}\text { Jumlah Nilai investasi } \\
\text { berskala nasional }\end{array}$ \\
\hline & & $\begin{array}{ll}\text { Rasio daya } & \text { serap } \\
\text { tenaga kerja } & \\
\end{array}$ \\
\hline $\mathrm{D}$ & Aspek Daya Saing Daerah & \\
\hline \multirow[t]{2}{*}{ D.1 } & \multirow[t]{2}{*}{ Fokus Kemampuan Ekonomi Daerah } & \begin{tabular}{lrr} 
Angka & \multicolumn{2}{c}{ Konsumsi } \\
Rumah & Tangga per \\
Kapita & &
\end{tabular} \\
\hline & & Nilai Tukar Petani \\
\hline
\end{tabular}

\begin{tabular}{|c|c|c|}
\hline & & $\begin{array}{l}\text { Persentase Konsumsi } \\
\text { Rumah Tangga Non- } \\
\text { Pangan }\end{array}$ \\
\hline \multirow[t]{2}{*}{ D. 2} & \multirow[t]{2}{*}{ Fokus Fasilitas Wilayah/Infrastruktur } & $\begin{array}{lr}\text { Rasio } & \text { Ketaatan } \\
\text { Terhadap } & \text { Rencana } \\
\text { Tata Ruang } & \text { Wilavah }\end{array}$ \\
\hline & & $\begin{array}{l}\text { Persentase Wilayah } \\
\text { Produktif }\end{array}$ \\
\hline \multirow[t]{2}{*}{ D. 3} & \multirow[t]{2}{*}{ Fokus Iklim Berinvestasi } & Angka Kriminalitas \\
\hline & & Jumlah demonstasi \\
\hline \multirow[t]{2}{*}{ D. 4} & \multirow[t]{2}{*}{ Fokus Sumber Daya Manusia } & $\begin{array}{l}\text { Rasio } \\
\text { S1/S2/S3 }\end{array}$ \\
\hline & & Rasio ketergantungan \\
\hline
\end{tabular}

\section{B. Arsitektur Data TOGAF}

TOGAF[3] menyediakan sebuah metodologi untuk membangun arsitektur perusahaan, yang mencakup didalamnya arsitektur data. Arsitektur data dibagi menjadi empat bagian utama yaitu :

1) Businessi Vision

Alasan tersedianya arsitektur data adalah adanya visi akan nilai data yang harus tersedia sesuai prinsip data seperti keseragaman, keakuratan, dan seluruh data harus di peroleh dari sumber yang benar tanpa ada intervensi secara manual.

Berdasarkan visi ini standar dan kebijakan (policies) arsitektur data didefinisikan. Ruang lingkup arsitektur data di definisikan berdasarkan kebutuhan organisasi, yang pada penelitian ini dibatasi seperti tabel 1 .

\section{2) Data Management}

Kefektifan penggunaan data tergantung pada pengelolaan yang komprehensif. Tujuan dari aktivitas pengelolaan data adalah :

1. Mengidentifikasi data master, data rujukan (reference), dan data transaksional.

2. Mengidentifikasi pemanfaatan data oleh fungsi, proses, dan layanan bisnis.

3. Mengidentifikasi bagaimana dan dimana data dibuat, disimpan, dikirim, dan dilaporkan.

4. Mengidentifikasi tingkat konversi data dalam pertukaran informasi antar aplikasi.

5. Mengidentifikasi software yang dibutuhkan untuk integrasi sistem informasi.

3) Data Governance

Tata kelola data (data governance) memastikan enterprise memiliki tanggunjawab (accountability), kualitas (quality), integritas (integrity), dan keamanan (security) data. Tujuan dari tata kelola data adalah :

1. Mengidentifikasi struktur dan standar yang dibutuhkan untuk mengelola data.

2. Mengidentifikasi pegawai yang memiliki keterampilan dan wewenang untuk melakukan transformasi data di organisasi.

3. Mengidentifikasi entitas data untuk mengelola proses bisnis. 
4. Mengidentifikasi pengendalian dan kebutuhan pengarsipan data.

4) Gap Analysis

Analisis gap digunakan untuk memvalidasi sebuah arsitektur yang dibangun. Dasar pikirannya adalah untuk menyoroti deviasi antara arsitektur saat ini (baseline architecture) dengan yang dibangun (target architecture).

\section{METODE PENELITIAN}

\section{A. Metode Pengumpulan Data}

Perancangan blue print arsitektur data untuk analisa kondisi umum daerah membutuhkan data-data yang bersumber dari OPD yaitu Badan Perencanaan Penelitian dan Pengembangan Daerah (BAPELITBANG), Dinas Pendidikan (DISDIK), Dinas Kesehatan (DINKES), Badan Keuangan dan Aset Daerah (BKAD), Badan Pendapatan Daerah (BAPENDA), Dinas Penanaman Modal, Pelayanan Terpadu Satu Pintu (DPMPTSP), Dinas Kependudukan dan Pencatatan Sipil (DISDUK) yang diperoleh dengan cara:

1) Wawancara dan observasi

Wawancara dilakukan dengan responden dari OPD tersebut. Hasil dari wawacara dan observasi ini adalah daftar sistem informasi atau aplikasi yang dimiliki dan keluaran data yang dihasilkan dari masing-masing sistem tersebut yang berkaitan dengan kebutuhan data seperti tabel 1 .

\section{2) Studi Pustaka}

Studi pustaka dilakukan terhadap peraturan-peraturan yang berkaitan dengan perencanaan yaitu Peraturan Menteri Dalam Negeri No. 86 Tahun 2017 [1], jurnal, buku, dan sumber-sumber lain yang relevan.

\section{B. Metode Perancangan Arsitektur Data}

Metode perancangan arsitektur data menggunakan TOGAF yang dibatasi pada fase C Information System Architecture tahap arsitektur data. Pendekatan kerangka berfikir menggunakan bottom-up yang artinya penelitian dimulai dari menemukan solusi teknologi informasi untuk menyelesaikan permasalahan analisis kondisi umum daerah dalam rangka perencanaan pembangunan dengan cara membangun sebuah enterprise architecture yang diawali dari arsitektur data.

\section{PEMBAHASAN}

Bagian ini menjelaskan solusi singkat penyediaan informasi kondisi umum daerah dalam rangka memproyeksikan atau memprediksi (analytics) kondisi dan perkembangan pembangunan lima tahun yang akan datang. Berikut arsitektur bisnis yang di usulkan seperti gambar 2 .

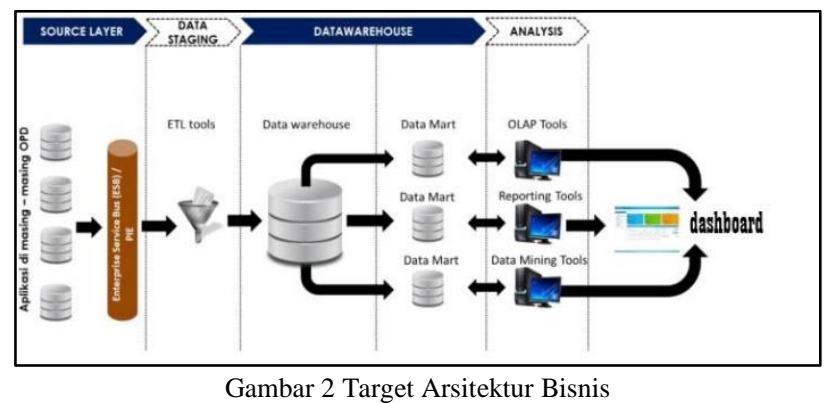

Arsitektur bisnis terdiri dari empat tahapan aliran data :

\section{1) Source Layer}

Sumber data berasal dari sistem atau aplikasi - aplikasi seluruh OPD. Sistem atau aplikasi yang akan dijadikan sumber data merupakan sistem atau aplikasi yang berada di seluruh OPD. Untuk mendapatkan data - data yang diinginkan perlu adanya proses penarikan data dari aplikasi aplikasi tersebut kepada enterprise data warehouse (EDW). Proses penarikan data berada pada tingkat basis data dan bukan pada tingkat aplikasi dengan Menggunakan teknologi Enterprise Service Bus (ESB) yang diberi nama PIE (Portal Interoperabilitas E-Government) [4].

\section{2) Data Staging}

Kumpulan data - data sumber yang didapatkan dari tahap pertama kemudian harus melalui proses ETL (Extract, Transform, Load) yaitu proses untuk melakukan ekstrak, integrasi, dan membersikan data sumber untuk diberikan kepada layer Data warehouse. Dalam proses ini kumpulan data - data tersebut akan di ekstrak, dibersihkan dan ditransformasi sehingga menjadi kumpulan data yang konsisten dengan satu format yang standar. Proses ETL terdapat empat fase yang terpisah, yaitu :

\section{Extraction}

Data - data yang relevan ditarik dari data sumber pada fase ini. Static extraction dilakukan ketika data warehouse membutuhkan populasi data untuk pertama kalinya, selanjutnya proses update dapat menggunakan Incremental extraction.

\section{Cleansing}

Fase ini merupakan tahap yang krusial dalam sistem data warehouse oleh karena fase ini terkait dengan peningkatan kualitas data. Hal - hal utama yang harus diperhatikan dalam fase ini :

a. Duplikasi data, yaitu suatu data yang sama tersimpan dalam sistem atau aplikasi yang berbeda.

b. Nilai yang tidak konsisten terkait secara logik, contohnya adalah alamat dan kode pos.

c. Data hilang.

d. Penggunaan field yang tidak semestinya, contohnya adalah field yang seharusnya berisi NIK ternyata diisi dengan data nomor handphone.

e. Nilai yang salah.

f. Nilai yang tidak konsisten untuk suatu entitas oleh karena perbedaan standar praktik yang digunakan. Contohnya adalah nama kota, penulisan pada suatu aplikasi 
menggunakan standar penamaan Tanjungpinang sedangkan pada aplikasi lain hanya menyebutkan $\mathrm{Tg}$. Pinang.

3. Transformation

Pada fase ini data dikonversi dari yang sebelumnya menggunakan format data sumber menjadi format data warehouse yang spesifik. Proses transformasi utama meliputi :

a. Konversi dan Normalisasi yang beroperasi pada format penyimpanan dan satuan ukur untuk membentuk data yang seragam.

b. Mencocokan field - field yang memiliki kesamaan dan saling terkait pada sumber - sumber yang berbeda.

c. Melakukan seleksi untuk menurunkan atau mengurangi jumlah field dan histori penyimpanan sehingga lebih efisien dan efektif.

4. Loading

Fase ini merupakan fase terakhir, loading dapat dijalankan dalam dua cara :

a. Refresh

Data warehouse sepenuhnya diubah. Yaitu data - data lama digantikan dengan data - data baru. Refresh biasanya digunakan dalam static extraction untuk menginisiasi populasi data dalam data warehouse.

\section{b. Update}

Perubahan pada data warehouse mengikuti perubahan sumber data. Update biasanya dijalankan tanpa menghapus atau memodifikasi data yang sudah ada. Teknik ini digunakan kombinasi dengan incremental extraction untuk memperbaharui data warehouse secara berkala.

3) Datawarehouse Layer

Data - data yang telah melalui proses ETL disimpan seluruhnya dalam data warehouse untuk kemudian di kategorisasi dan diberi label menjadi data mart yang berisi data - data spesifik[5].

\section{4) Analysis}

Pada layer ini, kumpulan data mart tersebut dianalisis dan diimplementasikan menjadi sebuah informasi - informasi penting dan strategik yang disajikan dalam bentuk visual [6].

\section{5) Dashboard}

Hasil keluaran dari tahap ini adalah menyajikan data dan informasi ke dalam dashboard [6].

\section{KESIMPULAN}

Penelitian perancangan arsitektur data pada fungsi analisis kondisi umum daerah masih dalam progres, yang selanjutnya akan dirancang yang berkenaan dengan data management, data governance, dan gap analysis. Namun demikian, penelitian ini telah menghasilkan sebuah target arsitektur; dengan adanya arsitektur ini memberikan sebuah gambaran tahapan dan komponen apa yang akan di implementasikan.

\section{UCAPAN TERIMA KASIH}

Penelitian ini secara tidak langung di dukung oleh BAPELITBANG kabupaten Bintan melalui diskusi-diskusi terutama dengan bidang PRK sehingga peneliti memiliki pemahaman mengenai perencanaan pembangunan daerah. Selain itu LPPM Sekolah Tinggi Teknologi Indonesia Tanjungpinang yang telah mendukung penelitian ini sehingga bisa dilaksanakan dengan baik.

\section{DAFTAR PUSTAKA}

[1] Peraturan Menteri Dalam Negeri Republik Indonesia No. 86 Tahun 2017.

[2] Prasetyo, Y.A. and Hanafi, R., 2016. Perancangan Enterprise Architecture Pada Fungsi Perencanaan Pembangunan Bappeda Kabupaten Bandung Menggunakan Framework Togaf Adm. eProceedings of Engineering, 3(2).

[3] Version, T.O.G.A.F., 2009. 9, the open group architecture framework (togaf). The Open Group, 1.

[4] Romdoni, M.R., 2013. Perancangan Portal Interoperabilitas eGovernment Sebagai Platform Integrasi Sistem Informasi Pemerintahan Kota Denpasar. Lontar Komputer: Jurnal Ilmiah Teknologi Informasi.

[5] Mohanty, S., Jagadeesh, M. and Srivatsa, H., 2013. Big data imperatives: Enterprise 'Big Data'warehouse, 'BI'implementations and analytics. Apress.

[6] Demchenko, Y., De Laat, C. and Membrey, P., 2014, May. Defining architecture components of the Big Data Ecosystem. In 2014 International Conference on Collaboration Technologies and Systems (CTS) (pp. 104-112). IEEE. 